\title{
RÁMÁNUDZSAN, EGY ZSENIÁLIS MATEMATIKUS
}

\section{AN INGENIOUS MATHEMATICIAN: RAMANUJAN}

\author{
Hujter Mihály \\ a matematika tudomány kandidátusa, egyetemi docens, Budapesti Műszaki és Gazdaságtudományi Egyetem Matematika Intézet \\ hujter@math.bme.hu
}

\section{ÖSSZEFOGLALÁS}

Száz éve hunyt el az Indiában és Angliában működő zseniális matematikus, akit a világ a keresztnevének angol változatán ismer: Rámánudzsan (Ramanujan). Áttekintjük tragikus életét, isteni eredetűnek mutatkozó képességeit és lelkesítő hatását a modern matematika fejlődésére.

\section{ABSTRACT}

The ingenious mathematician of India and England, whom the world knows by his given name, Ramanujan, passed away a century ago. We overview his tragic life, his divine abilities, and his enthusiastic influence on modern mathematics.

Kulcsszavak: Rámánudzsan, Hardy, Bertrand-posztulátum, matematikai rejtvények, trigonometria

Keywords: Ramanujan, Hardy, Bertrand postulate, mathematical puzzles, trigonometry

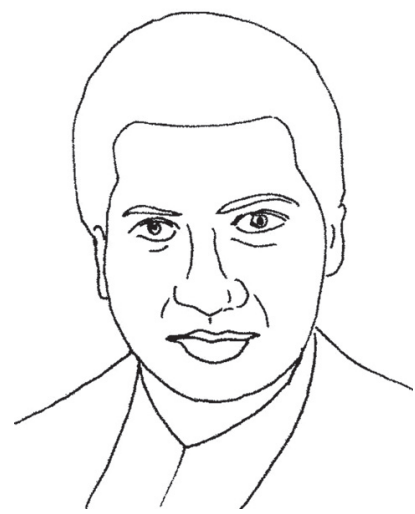

Sz. Rámánudzsan

(Bérczi Szaniszló (C) tollrajza) 


\section{BEVEZETÉS}

Joggal merül fel a kérdés: Miért jó a Magyar Tudományban egy olyan személlyel foglalkozni, aki már egy évszázada meghalt, és amíg élt, akkor is csak Indiában és Angliában tevékenykedett, és nagyon is fura figura volt? Kiugróan jól számolt, de a környezetével nehézkes, problémás volt a kapcsolata. Az orvostudomány mai állása szerint vélhetően az Asperger-szindróma elszenvedője volt, ahogyan például Isaac Newton és Albert Einstein esetében is ez a feltételezés.

Írásunk címszereplője egyszer éppen vegetáriánus vacsorájának elkészítésével foglalatoskodott, amikor egy honfitárs kollégája megkérdezte, meg tudná-e oldani az egyik londoni lap karácsonyra kitüzött, de túl nehéz feladványát:

Egy utcasorban ötvennél több, de ötszáznál kevesebb ház áll, szabályosan az elsőtől az utolsóig megszámozva. Melyik az a ház, amelytől balra a házszámok összege ugyanannyi, mint a jobbra?

Ha 10-nél kevesebb ház lenne, rögvest kijönne, hogy a hatodik, mert $1+2+$ $3+4+5=15=7+8$. De félszáznál több ház esetében beleveszünk a rengeteg lehetőség latolgatásába. Hősünk rávágta, hogy a kérdéses sorszám: 204. Hány házból? 288. De hogy a csudában lehet erre rájönni? A kurta magyarázat: lánctörtekkel. (A rövid beszélgetés során a zöldségek tisztítása zavartalanul folytatódott.)

Miért foglalkozunk egy ilyen fura figurával? Csak a celebek iránti vétkes kíváncsiságból? Egyrészt, mert Rámánudzsan a huszadik század elejének egyik legfontosabb matematikusa. Annyira megelőzte korát, hogy az eredményeinek mélységeit csak generációkkal később ismerték fel igazán. Másrészt, mert Rámánudzsan sok okos fiatalnak adott önbizalmat. A magyarok közül Erdős Pál és Turán Pál emelhetők ki, akik R. sikerein fellelkesedve kezdték kutató matematikusi pályájukat. Még túlszárnyalniuk is sikerült a példaképüket!

\section{SZÜLETÉSE ÉS GYERMEKKORA}

Mindenekelőtt beszéljük meg R. nevének helyes írásmódját. Angolul teljes az egyetértés, hogy a név Ramanujan változatban írandó. (Ez ugyan eredetileg first name - magyar megfogalmazásban utónév -, de a világ family name - családnév - értelemben használja.) Magyarországon is ez a név volt használatos sokáig. R. tamil volt, és a tamil írás nem latin betüs, így a magyar helyesírás szabályai szerint az eredeti kiejtéshez legjobban hasonlító, de magyarul kiolvasandó módon kell leírni a nevet. Sajnálatos azonban, hogy az utóbbi években a helytelen Rámánudzsan írásmód terjedt el. Az utolsó magánhangzót a világban senki sem ejti $a$-nak, még á-nak is csak ritkán, hanem leggyakrabban olyan nyílt e-nek mondják, mint a közép-dunántúli tájnyelvben az ember szó első $e$-je. 
Tehát Rámánudzsen ${ }^{1}$ a helyes magyar írásmód! (Már csak azért sem írhatunk $a$-t, mert csak az olyan angol szavaknál ejtünk a magyar $a$-hoz hasonló hangot, ahol $o$ vagy $u$ betü van leírva.)

Szrínivázá Rámánudzsan (saját, angolos írásmódjával: Srinivasa Ramanujan) 1887. december 22-én született Indiai déli csücskén, „A tamil nép hazája” - Tamilnádu nevü, brit fennhatóságú államban, mely akkoriban körülbelül tízmilliós népességü volt a mi (mai) hazánkénál másfélszer nagyobb területen. A Szrínivázá családnévhez a fiú a keresztnevet Rámánudzsácsárjá iránti tiszteletből kapta, aki a tizenkettedik század elején a hinduizmus egyik prófétájaként müködött. Az apa könyvelő volt egy szárikat árusító üzletben, az anya háztartásbeli. Hősünk Kumbakonam városban nevelkedett. Öccse három hónaposan meghalt, 1889-ben a himlöjárványban R. is megbetegedett, aztán még két újabb kistestvért veszített el.

Hároméves korára sem kezdett beszélni, ezért anyai nagyapja hangos felolvasással rizsszemek közé tamil írásjeleket írt neki. Még nem volt ötéves, már iskolába küldték, de megszökdösött. Apai nagyapja meghalt, anyai nagyszülei időközben a tamil nevén Csennai, de akkoriban még Madrász néven emlegetett milliós nagyvárosba költöztek, ezért R. odakerült. Tízévesen letette az elemi iskola vizsgáit, az egész tankerület legjobbjaként. Középiskolásként, tizenegy évesen már lekörözte tudásával a házuk föiskolás lakóit; tizenkét évesen trigonometria témájú könyvet olvasott, tizenhárom évesen önálló matematikai eredményei is lettek. Ki másra bízták volna az iskola 1200 diákja és harmincöt tanára órarendjének elkészítését, mint a tizennégy éves csodagyerekre?

\section{MÁR KÉSZ MATEMATIKUS}

Tizenhét évesen hallott a harmadfokú egyenletekre vonatkozó Cardano-képletről, és a negyedfokú egyenletek megoldására már maga is rájött. Nemsokára 15 jegy pontossággal kiszámította a Leonhard Euler és Lorenzo Mascheroni matematikusokról elnevezett konstans értékét: 0,577215664901532... Középiskolai tanulmányait 1904-ben fejezte be, matematikai díjjal tüntették ki. Kumbakonamban tanulhatott ösztöndíjjal az ottani müvészeti föiskolán, de annyira csak a matematika érdekelte, hogy több tárgyból megbukott, az ösztöndíjat megvonták. Újra Madrászba került, egy college-ban folytatta felsőfokú tanulmányait. Dolgozatait félkészen adta be; csak arról írt, ami izgatta. Így aztán 1906-ban és 1907ben is megbukott az államvizsgán. Diploma nélkül is csak a számításainak, a formuláinak élt. A himlőfertőzése óta életének a legnehezebb időszakát élte, az éhhalál küszöbén.

\footnotetext{
${ }^{1}$ A szerkesztőség tiszteletben tartja a szerző különvéleményét a név átírásával kapcsolatban, de megtartja a hagyományos írásmódot.
} 
A kor és a hely szokásainak megfelelően 1909-ben anyja megházasította. A tízéves ara három évvel később költözött férjéhez. Akkoriban még herevizsérv miatt is szenvedve R. szerény állásért esedezett; jobb híján föiskolásokat korrepetált, és a kikötőnek könyvelt.

\section{ELISMERÉSÉRT KOLDUL}

Miután 1913 májusában kétéves kutatói ösztöndíjat nyert Madrász egyetemére, neves indiai matematikusoknak küldte el tételeit, akik azokat (kellő hozzáértés hiányában) egymáshoz tologatták. Ezután R. angol matematikusokat kért fel levélben, hogy segítsenek. Többen nemet mondtak. Szerencsére a Cambridge-i Egyetemen dolgozó G. H. [Godfrey Harold] Hardy (1877-1947), aki az előbbieknél sokkal fiatalabb volt, és aki már többször kapott leveleket önjelölt zseniktől, csak átnézte az $S$. Ramanujan aláírású küldemény több tucat állítását, és nem tudván eldönteni, hogy nem beugratásról van-e szó, megmutatta a levelet kollégájának, J. E. [John Edensor] Littlewood (1885-1977) professzornak. Sok oldalon tömény matematikai képletek indoklások nélkül, de olvashatóan írva! Olyan állításokat is találtak, amelyekhez hasonlókat még húszévesen maga Hardy is bizonyított, ezért helyességükben reménykedve kezdték megvizsgálni a többit is.

Végül Hardy lelkesen ismertette R. eredményeit Angliában, és levélben megkérdezte, nem bizalmatlanságból maradtak-e le a bizonyítások. Csak helyhiány miatt! Vaskosabb borítékra már nagyon sok bélyeg kellett volna.

Hősünk anyja álmot látott: fehér emberek körbecsodálták a fiát, és Namagiri istennő kiadta az anyának, ne állja el gyermeke útját. Így R. Angliába utazhatott. Feleségét kímélve egyedül szállt hajóra, és 1914 áprilisában érkezett Londonba. (Még Indiában a barátok töltötték meg az útiládát cipővel, zoknival, sállal.)

\section{SZORGOS, DE NEHÉZ ÉVEK ANGLIÁBAN}

Keserves élete volt a ködös Albionban! Éjjel didergett, hisz nem tudta, hogy az ágyvégi takarót ki lehet göngyölíteni. Vallásának étrendi szigora és a háborús áruhiány miatt nem ehetett rendesen. Sem megszokni, sem megszökni nem tudván, egyre csak ontotta a meghökkentő matematikai eredményeket.

Olyanokat mondott például, hogy tizenkétszer $1+2+3+4+\ldots$ éppen mínusz egy. Úgy igaz ez (legalábbis felsőbb matematikával igazként is értelmezhető), mint például az, hogy kilencszer $1 / 10+1 / 100+1 / 1000+\ldots$ éppen egy! A középkorban még ezt sem ismerték volna el, de ma már lesajnáljuk, akinek ez magas. 
Tragikus hősünk megelőzte a korát! (Az izgalmas téma iránt érdeklődőnek a $R a$ manujan summation keresőszavakat ajánljuk.)

Turán Pál (1910-1976) első jelentős eredménye Hardy és R. egy közös tételére adott egyszerủ bizonyítás, mely később a valószínűségek számításainak a számelmélet területén való hasznos alkalmazásait tette lehetővé. (A közös tételt R. ötlötte ki, és H. vajúdott, hogy megszülje a bizonyítást.)

Erdős Pál (1913-1996), aki a Hungarian Ramanujan volt, mondta, hogy a régi görögök tudták, végtelen sok prím van, és a modern tudomány még mindig csak ezt tudja. A végtelen sok prím mennyire sürün sorakozik fel? Prímhézag az egymás utáni prímek különbsége. Az átlag prímhézag nagyon lassan és nem teljes egyenletességgel növekszik. Nincs legnagyobb prímhézag. Joseph Bertrand (1822-1900) francia matematikus 1845-ben megfogalmazta, hogy mindegyik prímet egy nála kisebb prímhézag követi. Az orosz Pafnutyij Lvovics Csebisev (1821-1894) sikeresen bizonyította ezt, de a győzelemhez a matematika akkori nehézfegyverzetét is felvonultatta. Fél évszázad múlva $R$. meglelte a vágyott egyszerűbb bizonyítást, a sikeren fellelkesedve másfél évtizeddel később Erdős (müegyetemi gólyaként) még frappánsabbat talált. Az egyik alapötlet az volt, hogy meg kell vizsgálni a Pascal-háromszög közepét. (Hogy honnan az ihlet, nem tudjuk.)

Ragyogó eredményei a dúló világháború ellenére is hamar világhírüvé tették Rámánudzsant. A Fellow of the Royal Society és a Fellow of Trinity College megtisztelő címeket is elnyerte.

\section{AZ UTOLSÓ KÉT ESZTENDŐ}

A világháború elhúzódott, hősünk nem tudott hazatérni a feleségéhez. Pénze volt már, de gyakorlatilag éhezett, az egészsége meg csak romlott. Az angol doktorok tanakodtak, hogy a babkonzerveket forrasztó ólom mérgezte-e meg? Vagy a korábbi sérvbaja is rosszindulatú daganat volt már? Netán elkapta a tébécét? Egyre erőtlenebbül ugyan, de hősünk csak alkotta tovább merészebbnél merészebb, de előbb-utóbb rendre helyesnek bizonyuló képleteit, állításait. Sokszor nem is levezette, kigondolta, hanem csak megálmodta azokat! Az isteni sugallatoknak Rámánudzsácsárjá próféta kisöccse gyors és pontos könyvelője volt.

Itt nem áll módunkban R. eredményeit részletesen bemutatni. Kiragadunk egyet, kettő lesz belőle: Tekintsük 40 fok, 80 fok és 160 fok koszinuszának köbgyökét, tehát két pozitív és egy negatív számot. (Körzővel, vonalzóval egyik szám sem szerkeszthető meg.) Az már közismert volt, hogy a három szám köbének összege 0 , és a három szám reciproka köbének összege 6 . Főhősünk a tekintett három szám összegét is felírta egész számokból alapmüveletekkel és köbgyökök vonásával. Sőt a reciprokokét is! 


$$
\begin{aligned}
& \sqrt[3]{\cos 40^{\circ}}+\sqrt[3]{\cos 80^{\circ}}+\sqrt[3]{\cos 160^{\circ}}=\frac{\sqrt[3]{3} \cdot \sqrt[3]{\sqrt[3]{9}-2}}{\sqrt[3]{2}} \\
& \frac{1}{\sqrt[3]{\cos 40^{\circ}}}+\frac{1}{\sqrt[3]{\cos 80^{\circ}}}+\frac{1}{\sqrt[3]{\cos 160^{\circ}}}=\frac{\sqrt[3]{6} \cdot(\sqrt[3]{3}-1)}{\sqrt[3]{\sqrt[3]{9}-2}}
\end{aligned}
$$

Aki nem hiszi, számoljon utána! Az eredményeket 8 jegy pontossággal adja meg a matematikusoknak, és kérdezze meg, hogyan jönnek ki azok egyjegyü számokból alapmüveletekkel és köbgyökvonásokkal! Persze, hogy nem tudják! (A jelen sorok írója utánajárt a bizonyításoknak. Ráment egy munkanapja, de nagyon tanulságos volt az aprólékos vizsgálódás.)

Amikor kórházi ápolásokkal R. egészsége már kissé feljavult, és a háború is kifulladt, hősünk hazatért szülőföldjére. Szerető hitvese gondos ápolása ellenére 1920. április 26-án elhunyt. Valamelyik régi betegsége vitte el? Vagy talán egy helyi járvány? Halálával a tudomány nagyon sokat veszített! Kéziratai ránk maradtak, ha néhány zsák fecnit a kazánba öntés elől kellett elrejteni.

\section{RÁMÁNUDZSAN HAGYATÉKA ÉS KULTUSZA}

A hagyaték tanulmányozása révén lassacskán némi fény derül R. titkaira. A házszámos rejtvénynél az $1+1 / 2,1+1 /(2+1 / 2), 1+1 /(2+1 /(2+1 / 2))$ stb. lánctörteket kell egyszerüsítenünk, hogy megkapjuk a 3/2, 7/5, 17/12 stb. törteket, és most már csak össze kell szoroznunk a számlálót és a nevezőt, hogy kinyerjük a 6, 35, $204 \ldots$ számokat. És lássunk csodát, mert ahogyan a 6-nál kisebb pozitív egész számok összege kirakható a 6-nál nagyobb szomszédokból, hasonló igaz a 35-nél, illetve a 204-nél kisebb számok összegére is: $1+2+\ldots+34=595=36+37+\ldots$ $+49 ; 1+2+\ldots+203=20706=205+206+\ldots+288$. Mindezt bizonyítani tudjuk már, de fogalmunk sincs, hogyan lehetett ezeket kitalálni pár másodperc alatt!

Annak szemléltetésére, hogy R. eredményei és módszerei évszázadokat átölelő jelentőségűek, elmesélünk a matematika történetéből egy eseményláncot.

Joseph-Louis Lagrange (1736-1813) olaszból lett francia matematikus 1770ben kimondta: Minden pozitív egész szám felírható négy négyzetszám összegeként. (Itt a nulla is négyzetszám.) R. 1916-ban publikálta, hogy mely konkrét $a, b$, $c, d$ pozitív egészekre igaz egy hasonló állítás olyan értelemben, hogy a négyzetszámokat nem feltétlenül egyszer-egyszer vesszük, hanem az elsőt $a$-szor, a másodikat $b$-szer, a harmadikat $c$-szer, a negyediket $d$-szer. R. 54 darab ilyen $(a, b$, $c, d)$ számnégyest listázott, az egyik például $(1,1,2,3)$. A felvetett kérdéskör egy általánosabb változatának lezárását kilencven évvel később érte el Manjul Bhar- 
gava és Jonathan Hanke. Munkájukban Hardy és R. egyik híres módszerére és a moduláris formák elméletére támaszkodtak (az utóbbi elindításában is komoly szerepe volt R.-nak). Manjul Bhargava (1974-) indiai származású kanadai-amerikai kutató 2014-ben Fields-érmet kapott, ami a világ fiatal matematikusainak a legrangosabb elismerése.

India ma már nagyon büszke szülöttjére, R.-ra. Egy rangos folyóirat viseli a nevét: The Ramanujan Journal (An International Journal Devoted to the Areas of Mathematics Influenced by Ramanujan).

A R.-szakirodalom már szerfelett kiterjedt. Itt, az írásunk végén csak két jó kiindulási pontot adunk meg az érdeklődőknek. Óvatosságra intjük azonban az olvasót, mert a hatalmas és érdekes témában könnyü elmerülni. Pólya György (1887-1985) is egyszer pánikszerüen adta vissza Hardynak a kölcsönkért Rámánudzsan-kéziratokat, mert nem akart bezáródni a formulák bủvkörébe, hiszen akkor egész életében azok bizonyításával foglalkozna, és nem jutna ideje semmi másra. Arra is intjük az olvasót, hogy a R.-ról szóló népszerü cikkek, könyvek, filmek, müalkotások leegyszerüsítő, megszépítő, néha túlzó híradását kellő óvatossággal fogadja.

\section{IRODALOM}

História Tudósnaptár, 2020: Ramanujan, https://tudosnaptar.kfki.hu/historia/egyen.php?namene$\mathrm{v}=$ ramanujan

Turán P. (1977): Egy különös életút: Ramanujan, I. és II. Középiskolai Matematikai Lapok, 27, 49-54, 97-106. http://db.komal.hu/scan/1977/10, http://db.komal.hu/scan/1977/11 